\title{
Future EU Funding: a Case of Lump-Sum Tax
}

\author{
Marian Dobranschi, Danuse Nerudova, Veronika Solilova
}

\author{
Mendel University of Brno, Czech Republic \\ Zemedelska 1/613 00, Brno, Czech Republic \\ E-mail.marian.dobranschi@mendelu.cz,danuse.nerudova@mendelu.cz,veronika.solilova@mendelu.cz.
}

cross $^{\text {ref }}$ http://dx.doi.org/10.5755/j01.ee.28.4.16498

\begin{abstract}
This paper is concerned with the EU financing reform, where the lump-sum tax is considered as an alternative source of revenue. The purpose of this study stems out of the current debate related to the EU budget reform, where tax-based ownresources are required to replace the current system of own resources of the EU budget. The novelty of this research arises from the evaluation of a hypothetical EU lump-sum tax as a future replacement of GNI and VAT-based EU budget own sources. The aim of this paper is to analyze the potential of a lump-sum tax as a source of future EU funding. We consider lump-sum tax as an EU per capita charge applicable to all citizens of 28 EU member states. In order to assess the lump-sum tax potential we simulate five different lump-sum tax rates and compare the obtained yield to current EU own resources. The results of the research show that a charge per capita in the EU does not have the capacity to fully replace GNI or VAT-based EU own resources. Therefore, we consider the EU per capita charge as a form of complementary source to fund the EU own budget, with no real potential to fully replace the current EU own resources.
\end{abstract}

Keywords: EU Budget, Lump-Sum Taxation, Future EU Taxes, Tax Revenue Potential, Sustainability Gaps.

\section{Introduction}

Currently, the European Union is facing an intense debate on a necessary reform of the EU budget revenues, especially on a different set of resources, which should replace the present system of the EU budget own resources. There can be found number of arguments for support of the reform of the EU budget in discussions. The current design of the EU budget revenues lacks transparency, is prone to complicate adjustments and has low autonomy due to its dependence on GNI and VAT-based resources, as underlined by Sapir (2003), Le Cacheux (2005), Cipriani (2007) Fuest, Heinemann \& Ungerer (2015) and Schratzenstaller et al. (2016). Moreover, Richter (2006) and Cipriani (2007) express the concern that the current system of financing the EU budget does not support the European added value and does not enhance the economies of scale at the EU level. Our research was conducted on the background of the most critique argument of current status quo, that there is no real connection between the present composition of the EU budget revenues and the Europe2020 strategy of smart, sustainable and inclusive growth established by the European Commission in 2010.

In the search for new own resources, the standard literature proposes several candidates for the future EU taxes, such as Financial Transaction Tax (FTT), European Union Income Tax, EU VAT tax. There can also be found innovative candidates as the EU energy tax and also the EU carbon-based flight ticket tax or Common (Consolidated) Corporate Tax Base. It is necessary to mention, that the lump-sum taxation has not been considered by the existent literature as a possible candidate for the future EU tax yet.

The scientific problem this paper is focusing on the possible reform of revenue side of the EU budget and the possibility of enacting the future EU lump-sum tax as an appropriate replacement of the current system of the EU budget own resources. The aim of the paper is not only to estimate the revenue potential of the lump-sum tax with respect to the EU budget, but also to evaluate whether it could be a useful instrument for closing in the sustainability gaps of current tax systems across the EU as defined by Schratzenstaller et al. (2016).

The methodology used in this research is qualitative and quantitative analysis. In the first part of this paper we review the literature regarding the issues of the EU budget and also the experiences related with the lump-sum taxation enactment. In the second part of this paper we use qualitative analysis to assess the ability of the lump-sum tax to close the sustainability gaps of tax system in the form of the future EU tax. Also we evaluate empirically the revenue potential of the lump-sum tax at the EU level and compare its potential of per capita tax imposed yearly with the current system of the EU budget sources of revenues. This paper presents the results of the research within the crossdisciplinary H2020 EU project FairTax No. 649439, "Revisioning the 'Fiscal EU': Fair, Sustainable, and Coordinated Tax and Social Policies".

\section{The Need for the Reform}

The EU budget finances are regulated by Articles 310 and 311 of Treaty on the Functioning of the European Union. According to this treaty, the EU is not allowed to run budget deficits and financing through public debt is excluded. The structure of the EU budget own resources has evolved through time, where a dominant trend of permanent increase of GNI-based resources share in total EU own resources is present. The current system of the EU own revenues is financed predominantly by own resources, which amount up to $94 \%$ of total revenues. The rest of 6 
$\%$ is financed through other revenues collected from taxes paid by the EU staff salaries, fines and contributions from the non-EU states. The GNI-based resource bears the highest percentage in own resources (68.9\% in 2015), the second place is occupied by Traditional Own Resources (TOR) which amount up to $12.8 \%$ in 2015 and VATbased resources (12.3\% in 2015).

The GNI and VAT-based resources in total revenues of the EU budget represent direct contribution from national budgets of each EU member state. Cipriani (2007) points out that these contributions raise the national awareness of the cost of the EU budget, and creates the ongoing debate between net payers and net recipients, especially regarding the benefits generated by the EU expenditures which are less visible at the national level.

Taking into account the current structure of the EU budget own resources, the literature reveals important weaknesses and disadvantages of the EU revenues, requiring a reform of own resources. Sapir (2003) considers that the current system of the EU own resources is a historical relic. The author underlines that all the procedures related to the EU revenues and expenditures do not reflect the present and future process of the EU integration. On the same rationale, Cipriani (2007) considers the current system of the EU budget resources to be opaque, complex and also outdated. Another weakness of the EU budget system of own resources consist into lack of connection between funding and spending on economic public goods that would increase the economies of scale at the EU level (Benedetto, 2013). Sapir (2003), Le Cacheux (2005, 2007), Cipriani (2007), Heinemann, Mohl \& Osterloh (2010), Neheider \& Santos (2011) and Schratzenstaller et al. (2016) argue that high dependence of the EU budget on GNI and VAT-based contributions from national budgets increases the juste retour rhetoric and insistent focus of the EU member state to improve the net balance position. Núñez-Ferrer (2007) and Schratzenstaller et al. (2016) consider that budgetary debates and lack of unanimity in terms of the EU budget revenues and spending leads to complicate adjustments, lack of transparency and low autonomy. Begg \& Heinemann (2006), underline that the current design of the EU finances raise issues regarding economic rationale, effectiveness and financial burden sharing among the EU member states. Neheider \& Santos (2011) and Cottarelli (2016) consider that EU budget effectiveness is affected by its size, which small in comparison with the EU GNI (1.23\% in 2015). With respect to its small size, the EU budget has low effectiveness compared with objectives intended to be reached and current policies pursued.

Sapir (2003), Tabellini (2003) and Cipriani (2007) point that there is no clear connection between the EU budget own resources and European added value. The concept of European added value is defined by Cipriani (2007) as the raison d'être of the EU budget. The author underlines that through the EU budget revenues and expenditure, the objectives can be achieved with better results and more efficiently than by each member state individually.

Another source of criticism regarding the efficiency of the current system of the EU budget own resources is the lack of connection with Europe2020 strategy. The
European Commission (2010) established a strategy of internalizing the structural weaknesses of the EU's economy. Thus, the Europe 2020 strategy devised a transformation towards smart, sustainable and inclusive growth, which would deliver higher levels of employment, productivity and social cohesion. According to the European Commission (2010) there are three mutually reinforcing priorities established by Europe2020 strategy: smart growth or developing an economy based on knowledge and innovation; sustainable growth or promoting a more resource efficient, greener and more competitive economy; and inclusive growth or enhancing high-employment economy or improving social and territorial cohesion. In this context, the EU budget and the policies financed at the EU level should follow the path underlined by Europe2020 strategy.

When considering the role of the EU budget in achieving the Europe2020 objectives, looking particularly at the revenue side, the aforementioned priorities can be easily transposed into the three pillars of sustainable development. Hence, the EU budget revenues should support economic, social and environmental sustainability as underlined firstly by Stiglitz, Fitoussi \& Sen (2010) and later by Schratzenstaller (2013), Nerudova et al. (2016) and Schratzenstaller et al. (2016). Taking into consideration the aforementioned papers, the literature require a reform of the EU budget own resources, proposing a switch from the current own resources to the future EU taxes that would replace GNI, VAT-based resources and TOR (Le Cacheux, 2005; Cipriani, 2007; Fenge \& Wrede (2007); Heinemann, Mohl \& Osterloch, 2008a; Heinemann, Mohl \& Osterloch, 2009; Schratzenstaller, 2013; Iara, 2015; Schratzenstaller et al., 2016).

In this context, where the future EU taxes represent appropriate instruments to replace the current system of the EU budget own resources, Cipriani (2007) proposes a set of criteria that the new own resources should fulfill: the system of revenues should be applicable to all the EU member states in the same manner; the system of revenues should be built-to-last and would not be subject to changes every financial framework; and also this system of revenues should be equitable, transparent, cost-effective and simple. In the same line Schratzenstaller (2013) considers that beside the traditional evaluation criteria, the future EU own taxes should be sustainability oriented achieving conditions such as: degree of regional attribution, mobility of tax base, short-term volatility and long-term yield, visibility and equality of gross-burdensharing at the national level. Furthermore, Schratzenstaller et al. (2016) argue that the future EU own tax should close in also the sustainability gaps of current tax systems across the EU, such as: increasing weight on labor taxes; decreasing progressivity of tax systems and increasing of income inequality; decreasing importance of Pigovian taxation that could internalize the cross-border negative externalities; intense tax competition; and decreasing tax compliance and issues with tax fraud.

\section{Experiences with Lump-Sum Tax in the EU}

The first trace of lump-sum taxation in the literature dates back to Adam Smith works (1776). Graaf (1987) 
considers that the lump-sum taxation as one of the simplest, most efficient and costless fiscal instrument. This opinion can even be found later in studies by Rothbard (1995) and Myles \& Hindricks (2004). The lump-sum tax in the literature is usually used as the ideal tool and also as a benchmark employed to compare the efficiency of secondbest tax instruments. The authors underline that lump-sum taxation is difficult to avoid, has no excess burden and does not create a substitution effect. Even if lump-sum taxation is considered highly efficient, Hillman (2003), Tam (2004) and Gans et al. (2011) argue that the disadvantages of lump-sum taxation arise from its disregard of ability-to-pay principle. The authors stress that the inseparability between efficiency and equity criteria lead to inapplicability of the lump-sum taxation in the real world. Gans et al. (2011) consider lumpsum taxation to be unfair, unethical and politically difficult to enact.

The lump-sum tax in the form of community charge was imposed in the UK aiming to replace a tax on property. The lump-sum tax was flat tax rate imposed on all individuals except few special groups of recipients (i.e. disable persons). The aversion against the UK lump-sum in the society tax was mainly caused by its high average rate, which affected low-income households. This poll tax was deemed as unfair, highly unpopular and regressive. Along the social unrest and unfairness the lump-sum tax abolition was triggered by the tax noncompliance. The individual's mobility proved to be the main cause of high administration costs related with lump-sum tax revenues collection. In some cases, the government spent more money in tracking the taxpayers (i.e. on tax administration) than the tax could bring to the public budget. Besley, Preston and Ridge (1997) analyze the noncompliance of lump-sum tax in the UK. The authors found that the UK's community charge noncompliance arose primarily from the high tax burden. On the other hand, tax noncompliance was also favored by avoiding registration in official documents of the individuals, which made tax administrative costs exceeding the tax revenues from the lump-sum tax. Myles and Hindricks (2004) examine the applicability and viability of the lump-sum tax, enacted in United Kingdom between 1986-1990, named formally "the Community charge" or the informal poll tax. The authors argue that the UK taxpayers could avoid the poll tax by ensuring that their name does not appear in any official registers. In the same line,

Rothbard (1995) considers that the community charge imposed during the Margaret Thatcher rule in the UK, was a bold and fascinating experiment for the public finance theory. The equal poll tax imposed for each UK's adult resulted in anti-tax riots across the entire country. The author notes that the government spent substantial resources in "hunting" the taxpayers that avoided the community charge payment. Another flaw of the UK lump-sum tax experience came from the fact that the tax did not have a lower limit. The size of the tax rate was left at the local councils to decide, which resulted in dramatic tax rate increase, where some households were supposed to pay a tax by $30 \%$ higher than before community charge enactment.

Against all the criticisms, the lump-sum tax regime can be found implemented in Luxembourg and Switzerland. According to Sansonetti, Hostettler, \& Funfschilling (2011) the lump-sum tax was introduced in Switzerland in order to enhance tourism and economic benefits of Swiss state. The lump-sum tax has been adopted in all Cantons of Switzerland since 1948. However, this tax was present in Canton of Vaud and Canton of Geneva since 1862. Currently, the lump-sum tax is imposed under specific criteria, under which 5450 individuals are liable to pay lump-sum tax. In order to be eligible to lump-sum taxation in Switzerland, the individuals should not hold the Swiss citizenship and should not be engaged in any gainful activity on Swiss soil, but choose to live in Switzerland. The tax base for lump-sum taxation is calculated using the living expenditures, such as housing, food and clothing, education, sport and travel costs. Sansonetti, Hostettler \& Funfshilling (2011) argue that this type of tax regime is highly beneficial for wealthy and mobile individuals.

\section{The EU Lump-Sum Tax as an Option and Evaluation Methodology}

In order to research the ability of lump-sum taxation to become a potential candidate to replace GNI and VATbased EU own resources, we use both qualitative and quantitative analysis. Firstly, we measure the suitability of lump-sum tax using the traditional evaluation criteria of taxation proposed by European Commission (2004) and Heinemann, Mohl \& Osterloh (2008b). Moreover, we assess the capacity of the EU future lump-sum taxation to close-in the tax system sustainability gaps underlined by Schratzenstaller et al. (2016).

Secondly, we employ an empirical analysis of the future EU lump-sum tax revenue potential, by simulating five different tax rates imposed on all the EU citizens and also citizens aged between 15-64 years from the EU member states. Furthermore, with the obtained results from the simulations, we compare the ability of the EU lumpsum tax to replace the current system of the EU budget own resources.

The proposed the EU own resource reform which would require a switch from the current system of revenues to the future EU own taxes, represents a lengthy and laborious process. At first glance, this switch would have to overtake many obstacles from fiscal and political dimension. The critics of such reform might point the political barriers to be overcome in order to impose a stable and sufficient set of the future EU taxes, taking into consideration that a system of the EU own resources is already established. However, taxes do not represents just tools to collect revenues at the EU Budget, but taxes have an in-built fiscal leverage effect, which are more efficient than GNI-based resources to stimulate smart, sustainable and inclusive growth and also higher ability to close in the sustainability gaps.

The motivation concerning the enactment of the future EU lump-sum tax, by imposing flat tax rate for the each EU citizen, is due to the fact that all of them enjoy and benefit from the EU socio-economic framework. Therefore, this tax treats equals equally - regardless of income, wealth, endowment and preferences - the EU citizens are considered to be equal in front of the law, human and property rights protection, free and equal access to the opportunities to self-developing both personally and professionally in the EU. Consequently, the objective of 
the EU lump-sum tax should refer exclusively to the benefits of individuals to be part of the European Union, such as: free movement of goods, services, labor and capital. Also, the EU citizens enjoy in this framework higher opportunities for personal and professional development. Thus, following the Ramsey principle of optimal taxation, the lump-sum tax base is represented by the observable characteristics of individuals to be citizens of an EU member state. Hence, the tax should be imposed solely on this condition, regardless of any other observables of the individuals (i.e. taste, ability, race, sex, income or wealth). The horizontal equity, in case of the uniform EU lump-sum tax treats equals equally, by considering the quality of being the EU citizen which benefit from this socio-economic framework, where they can travel, work, live and develop freely.

There can be done an extrapolation between Ramsey's optimal commodity taxation and the optimal lump-sum tax. Ramsey (1927) introduced the inverse elasticity rule of commodity taxation. An optimal commodity tax should have a broad tax base, affecting the production and consumption of goods on the large scale. Thus, the substitution effect would not appear and the tax will not affect greatly the consumption and production pattern. The behavior adjustment of the individual, taken as representative consumer or/and worker, seeks to pay less consumption and income tax. This behavior reaction creates the deadweight loss or the net economic loss with respect of resources allocation in the economy compared with no-tax world. Elkins (2006) argues that one way to reduce the efficiency loses is to impose a equal lump-sum tax on all individuals, which would create the same tax burden on every individual regardless of his behavior towards work and consumption. The author considers that the viability of the tax stays in the principle - the higher the elasticity the lower the tax rate, where the narrower the tax base the higher will be the elasticity. In this case the taxpayer can adjust his behavior in order to avoid paying taxes. In the opposite case when the tax base is broad the elasticity is low, and the taxpayer has little room to avoid the tax. Thus from this point of view the lump-sum tax base imposed on the EU citizens, has a broad tax base and there are few highly unlikely escape routes for avoiding the tax - migration or death.

In case of lump-sum tax, there is a debate regarding its connection to vertical and horizontal equity. Assuming that a uniform, flat tax rate imposed on the each EU citizen treats equals equally, the lump-sum tax respects the horizontal equity criteria. Having in mind previous features of lump-sum taxation, any differentiation and thus substitution effect triggering, the tax loses its lump-sum characteristics.

We choose also the evaluate the future EU lump-sum applicability, by taking into consideration the traditional evaluation criteria established by European Commission (2004) and also its ability to close in the sustainability gaps assessed by Schratzenstaller et al. (2016). In Table no.1 we firstly evaluate the lump-sum against the traditional evaluation criteria. The lump-sum taxation, as mentioned in previous section, is one of the simplest, transparent and cost-efficient tax instruments. Also, this tax has a high potential with respect to long-term yield. Lump-sum tax is not affected by mobility of tax base, due to the fact that the tax liability is exclusively related to the quality of the taxpayer to be the EU citizen. However, imposing lumpsum as flat tax per year for each citizen, the resulting degree of regional attribution is obvious. Also the lumpsum tax does not establish any links between tax base (the EU citizenship) and the national income. One of the most important evaluation criteria that the lump-sum tax is overlooking is the equity or the ability-to-pay of the taxpayers. Because lump-sum taxation is perceived to be highly inequitable, this feature plays a crucial role in applicability and sustainability of this levy in real world.

Evaluation of Lump-Sum Taxation as the Potential EU Tax

Table 1

\begin{tabular}{|c|c|}
\hline \multicolumn{2}{|c|}{ Traditional Evaluation Criteria } \\
\hline Equitable & No \\
\hline Transparent & Yes \\
\hline Cost-effective & Yes \\
\hline Simple & Yes \\
\hline Degree of regional attribution & Yes \\
\hline Mobility of tax base & No \\
\hline Short-term volatility & No \\
\hline Long-term yield & Yes \\
\hline Equality of gross-burden-sharing at the national level & No \\
\hline \multicolumn{2}{|c|}{ Potential to close in the tax system sustainability gaps } \\
\hline Decrease the weight on labor taxes & Yes \\
\hline Increase the tax system progressivity & No \\
\hline Decrease the income inequality & No \\
\hline Cross-border negative externalities internalization & No \\
\hline Decrease tax competition & No \\
\hline Increase the tax compliance & Yes \\
\hline Decrease of tax fraud & Yes \\
\hline
\end{tabular}

*Source: Adaptation after the evaluation criteria proposed by the European Commission (2004), Cipriani (2007), Schratzenstaller (2013) and Schratzenstaller et al. (2016). 
In Table no. 1 we use a Yes/No method to evaluate the ability of the lump-sum taxation to fulfill the selected evaluation criteria. In the second part of Table no. 1, we analyzed the ability of lump-sum taxation to close in the sustainability gaps pointed by Schratzenstaller et al. (2016). With respect to the capacity of the future EU lumpsum to decrease the weight on labor taxes, we consider that the switch to this levy could provide a relief of current tax system on labor taxes. In case of increasing the tax system progressivity gap, the lump-sum plays a minor role, where other tax instruments could close in this gap more efficiently. When referring to the ability of lump-sum tax to contribute to decrease of income inequality, the lump-sum tax has no role, due to the fact that this tax is by default ignoring the ability-to-pay of the taxpayer. Also, future lump-sum tax has no stimulus effect with respect to the internalization of cross-border negative externalities, such as pollution or to decrease the company tax competition.

With respect to the last two sustainability gaps presented in Table no.1, we consider that the future EU lump-sum could perform efficiently in decreasing the tax fraud and increasing tax compliance. Due to its simplicity and transparency, avoiding lump-sum tax is only possible through emigration or the taxpayer should cease to exist.

In examining the potential of revenues that a lump-sum tax could collect to the EU budget, we use the data regarding the population size of EU 28 countries. The data employed is for the year 2014, where the European Union had a population of 506.94 million. Thus, as shown in the Table no. 2, we explore the potential of lump-sum tax in the EU, applied as yearly uniform flat tax rate per person. We use five different tax rates in order to assess the potential tax revenues that the head tax could produce.

The calculation is started with a lower level of EUR 1 charge per person paid each year. The second level increases the tax rate to EUR 3.65, assuming that every EU citizen is liable to pay EUR Cent 1 per day. The last 3 tax rates take into account EUR 5, EUR 10 and EUR 100 per person which should be paid annually.

The EU Lump-Sum Tax Revenues Potential Estimation Using 2014 Level of Population

\begin{tabular}{|c|c|c|c|c|c|c|}
\hline & Population & Ls (1 EUR) & Ls (1 EUR Cent/day) & Ls (5 EUR) & Ls (10 EUR) & Ls (100 EUR) \\
\hline & Million & EUR Mil. & EUR Mil. & EUR Mil. & EUR Mil. & EUR Mil. \\
\hline EU (28 countries) & 506.94 & 506.94 & 1850.35 & 2534.72 & 5069.44 & 50694.41 \\
\hline Belgium & 11.20 & 11.20 & 40.89 & 56.02 & 112.04 & 1120.40 \\
\hline Bulgaria & 7.25 & 7.25 & 26.45 & 36.23 & 72.46 & 724.57 \\
\hline Czech Republic & 10.51 & 10.51 & 38.37 & 52.56 & 105.12 & 1051.24 \\
\hline Denmark & 5.63 & 5.63 & 20.54 & 28.14 & 56.27 & 562.72 \\
\hline Germany & 80.77 & 80.77 & 294.80 & 403.84 & 807.67 & 8076.75 \\
\hline Estonia & 1.32 & 1.32 & 4.80 & 6.58 & 13.16 & 131.58 \\
\hline Ireland & 4.61 & 4.61 & 16.81 & 23.03 & 46.06 & 460.55 \\
\hline Greece & 10.93 & 10.93 & 39.88 & 54.63 & 109.27 & 1092.68 \\
\hline Spain & 46.51 & 46.51 & 169.77 & 232.56 & 465.12 & 4651.22 \\
\hline France & 65.89 & 65.89 & 240.50 & 329.45 & 658.89 & 6588.91 \\
\hline Croatia & 4.25 & 4.25 & 15.50 & 21.23 & 42.47 & 424.68 \\
\hline Italy & 60.78 & 60.78 & 221.86 & 303.91 & 607.83 & 6078.27 \\
\hline Cyprus & 0.86 & 0.86 & 3.13 & 4.29 & 8.58 & 85.80 \\
\hline Latvia & 2.00 & 2.00 & 7.31 & 10.01 & 20.01 & 200.15 \\
\hline Lithuania & 2.94 & 2.94 & 10.74 & 14.72 & 29.43 & 294.35 \\
\hline Luxembourg & 0.55 & 0.55 & 2.01 & 2.75 & 5.50 & 54.97 \\
\hline Hungary & 9.88 & 9.88 & 36.05 & 49.39 & 98.77 & 987.74 \\
\hline Malta & 0.43 & 0.43 & 1.55 & 2.13 & 4.25 & 42.54 \\
\hline Netherlands & 16.83 & 16.83 & 61.43 & 84.15 & 168.29 & 1682.93 \\
\hline Austria & 8.51 & 8.51 & 31.05 & 42.53 & 85.07 & 850.69 \\
\hline Poland & 38.02 & 38.02 & 138.77 & 190.09 & 380.18 & 3801.79 \\
\hline Portugal & 10.43 & 10.43 & 38.06 & 52.14 & 104.27 & 1042.73 \\
\hline Romania & 19.95 & 19.95 & 72.81 & 99.74 & 199.47 & 1994.73 \\
\hline Slovenia & 2.06 & 2.06 & 7.52 & 10.31 & 20.61 & 206.11 \\
\hline Slovakia & 5.42 & 5.42 & 19.77 & 27.08 & 54.16 & 541.59 \\
\hline Finland & 5.45 & 5.45 & 19.90 & 27.26 & 54.51 & 545.13 \\
\hline Sweden & 9.64 & 9.64 & 35.20 & 48.22 & 96.45 & 964.49 \\
\hline United Kingdom & 64.35 & 64.35 & 234.88 & 321.76 & 643.51 & 6435.12 \\
\hline
\end{tabular}

*Source: Own calculation based on Eurostat data; $L s=$ simulated the EU lump-sum tax rate.

In table no. 2 we simulate five different lump-sum tax rates applied at the EU level. The application of first two tax rates, conceived as the lowest level, would raise to the EU budget more than EUR 500 mil., an amount which would seem as very low compared with the current EU own resources. The EUR Cent 1 per day, paid by every EU citizen would collect at the end of the year close to EUR 1.8 bn. The 5 EUR lump-sum tax rate would bring EUR 2.5 Bn. and the EUR 10 tax rate would bring EUR $5.06 \mathrm{bn}$. to the EU budget. The last tax rate employed,
EUR 100 per person paid annually, would bring to the EU budget more than EUR $50 \mathrm{Bn}$., which is a substantial source of revenues. However, this higher limit of lumpsum tax is significantly regressive, imposing an unbearable burden on the low and middle income households.

As shown in the table no. 2, the tax revenues are copying the differences in population across the EU member states, such as Germany, France, Spain, Italy and Poland in comparison with the rest of the 28 EU countries. Thus, there is a default differentiation between the EU countries and 
their contribution to the EU budget through the lump-sum tax. Germany would be the country which contributes the most due to the high population level and Malta would generate the lowest volume of the tax revenues.
The below stated Table no. 3 presents the revenue potential of lump-sum tax in relation to overall contribution of the EU member states to the EU budget.

The Comparison between Lump-Sum Potential and the EU Budget from 2014

Table 3

\begin{tabular}{|l|c|c|c|c|c|c|c|}
\hline & \multicolumn{1}{|c|}{$\begin{array}{c}\text { EU Budget } \\
\text { EU14 }\end{array}$} & $\begin{array}{c}\text { Lump-sum } \\
\text { Tax Replace }\end{array}$ & $\begin{array}{c}\text { Ls (1 } \\
\text { EUR) }\end{array}$ & $\begin{array}{c}\text { Ls (1 EUR } \\
\text { Cent/day) }\end{array}$ & Ls (5 EUR) & $\begin{array}{c}\text { Ls (10 } \\
\text { EUR) }\end{array}$ & $\begin{array}{c}\text { Ls (100 } \\
\text { EUR) }\end{array}$ \\
\cline { 2 - 8 } & \multirow{2}{*}{ EUR Bn. } & & 0.51 & 1.85 & 2.53 & 5.07 & 50.69 \\
\cline { 2 - 8 } & & EUR & $\%$ & $\%$ & $\%$ & $\%$ & $\%$ \\
\hline VAT-based own resource & 17.67 & 34.85 & 2.87 & 10.47 & 14.35 & 28.69 & 286.94 \\
\hline GNI-based own resource & 99.08 & 195.44 & 0.51 & 1.87 & 2.56 & 5.12 & 51.17 \\
\hline $\begin{array}{l}\text { Traditional own resources (TOR) } \\
(75 \%)\end{array}$ & 16.43 & 32.41 & 3.09 & 11.26 & 15.43 & 30.86 & 308.56 \\
\hline Customs duties (100\%) & 22.00 & 43.39 & 2.30 & 8.41 & 11.52 & 23.04 & 230.45 \\
\hline $\begin{array}{l}\text { Amounts (25\%) retained as TOR } \\
\text { collection costs (-) }\end{array}$ & 5.54 & 10.93 & 9.15 & 33.38 & 45.73 & 91.45 & 914.52 \\
\hline Other revenue & 9.97 & 19.67 & 5.08 & 18.55 & 25.41 & 50.83 & 508.30 \\
\hline Gross National Income (GNI) & 139.22 & 274.62 & 0.36 & 1.33 & 1.82 & 3.64 & 36.41 \\
\hline TOTAL own resources & 132.96 & 262.28 & 0.38 & 1.39 & 1.91 & 3.81 & 38.13 \\
\hline TOTAL national contribution & 116.53 & 229.87 & 0.44 & 1.59 & 2.18 & 4.35 & 43.50 \\
\hline TOTAL REVENUE & 143.94 & 283.94 & 0.35 & 1.29 & 1.76 & 3.52 & 35.22 \\
\hline TOTAL EU EXPENDITURE & 128.56 & 253.61 & 0.39 & 1.44 & 1.97 & 3.94 & 39.43 \\
\hline TOTAL Expenditure & 142.50 & 281.09 & 0.36 & 1.30 & 1.78 & 3.56 & 35.58 \\
\hline Surplus from previous year & 1.01 & $\mathrm{n} / \mathrm{a}$ & $\mathrm{n} / \mathrm{a}$ & $\mathrm{n} / \mathrm{a}$ & $\mathrm{n} / \mathrm{a}$ & $\mathrm{n} / \mathrm{a}$ & $\mathrm{n} / \mathrm{a}$ \\
\hline
\end{tabular}

*Source: Own calculations based on Eurostat data; Ls = simulated EU lump-sum tax rate.

In Table no. 3 we compare the obtained results after simulation with the EU budget own resources. The second column shows the size of the EU lump-sum tax applied as charge per person in order to fully replace each component of the current EU own resources. As shown in Table no. 3, in order to replace the VAT-based resources, every EU citizen would have to pay EUR 34.85 person/year. On the other hand, to completely replace the GNI-based resources, the EU citizens would have to pay EUR 195.44 person/year. Finally, a lump-sum tax of EUR 283.94 person/year paid annually should be imposed to replace the entire system of EU own resources. This uniform tax rate applied yearly for the every EU citizen is highly regressive when low and middle income households are taken into account. For a couple with more than 3 dependent children, the total lump-sum tax would exceed EUR 1700 per year.
Also in Table no. 3 we compared the obtained results for each lump-sum tax rate (i.e. EUR 1 person/year; EUR 3.65 person/year; EUR 5 person/year; EUR 10 person/year and EUR 100 person/year) with the EU own resources and expenditures incurred for 2014, expressed in percentage. The first tax rate would only cover $0.39 \%$ of the total EU budget revenues. The next two tax rates of the proposed lump-sum tax would cover between 1.3 and $1.8 \%$ of total revenues collected in 2014. The EUR 10 person/year lumpsum tax would cover less than $4 \%$ of total revenues, and the highest lump-sum tax rate of EUR 100 person/year would cover only $40 \%$ of total revenues collected to the EU budget. Therefore, the EU lump-sum tax ability to collect revenues to the EU budget is strictly limited to the size of the tax, which is crucial for the applicability and the acceptance of this tax in the EU.

Table 4

The EU Lump-Sum Tax Revenues Potential Estimation Using 2014 Level of Population Aged between 15 - 64 Years Old and the EU Budget from 2014

\begin{tabular}{|c|c|c|c|c|c|c|c|}
\hline \multirow{4}{*}{ EU-28 } & \multirow{2}{*}{$\begin{array}{c}2014 \\
\text { EU Own } \\
\text { Resource } \\
\text { s } \\
\end{array}$} & \multirow{2}{*}{$\begin{array}{c}\text { Full } \\
\text { replacement } \\
\text { with lump- } \\
\text { sum tax }\end{array}$} & Ls (1 EUR) & $\begin{array}{l}\text { Ls (1 EUR } \\
\text { Cent/day) }\end{array}$ & $\begin{array}{r}\text { Ls (5 } \\
\text { EUR) } \\
\end{array}$ & $\begin{array}{l}\text { Ls (10 } \\
\text { EUR) }\end{array}$ & $\begin{array}{l}\text { Ls }(100 \\
\text { EUR) }\end{array}$ \\
\hline & & & $\begin{array}{l}\text { EUR } \\
\text { Bn. }\end{array}$ & $\begin{array}{l}\text { EUR } \\
\mathrm{Bn} .\end{array}$ & $\begin{array}{l}\text { EUR } \\
\text { Bn. }\end{array}$ & $\begin{array}{l}\text { EUR } \\
\mathrm{Bn} .\end{array}$ & $\begin{array}{l}\text { EUR } \\
\mathrm{Bn} .\end{array}$ \\
\hline & \multirow{2}{*}{$\begin{array}{l}\text { EUR } \\
\text { Bn. }\end{array}$} & \multirow{2}{*}{ EUR } & 0.33 & 1.22 & 1.67 & 3.35 & 33.46 \\
\hline & & & $\%$ & $\%$ & $\%$ & $\%$ & $\%$ \\
\hline VAT-based own resource & 17.67 & 52.80 & 1.89 & 6.91 & 9.47 & 18.94 & 189.38 \\
\hline GNI-based own resource & 99.08 & 296.12 & 0.34 & 1.23 & 1.69 & 3.38 & 33.77 \\
\hline $\begin{array}{c}\text { Traditional own resources (TOR) } \\
(75 \%)\end{array}$ & 16.43 & 49.10 & 2.04 & 7.43 & 10.18 & 20.36 & 203.65 \\
\hline Customs duties (100\%) & 22.00 & 65.75 & 1.52 & 5.55 & 7.60 & 15.21 & 152.10 \\
\hline $\begin{array}{l}\text { Amounts }(25 \%) \text { retained as TOR } \\
\text { collection costs }(-)\end{array}$ & 5.54 & 16.57 & 6.04 & 22.03 & 30.18 & 60.36 & 603.58 \\
\hline Other revenue & 9.97 & 29.81 & 3.35 & 12.24 & 16.77 & 33.55 & 335.48 \\
\hline Gross National Income (GNI) & 139.22 & 416.09 & 0.24 & 0.88 & 1.20 & 2.40 & 24.03 \\
\hline TOTAL own resources & 132.96 & 397.39 & 0.25 & 0.92 & 1.26 & 2.52 & 25.16 \\
\hline TOTAL national contribution & 116.53 & 348.29 & 0.29 & 1.05 & 1.44 & 2.87 & 28.71 \\
\hline TOTAL REVENUE & 143.94 & 430.21 & 0.23 & 0.85 & 1.16 & 2.32 & 23.24 \\
\hline TOTAL EXPENDITURE & 128.56 & 384.25 & 0.26 & 0.95 & 1.30 & 2.60 & 26.02 \\
\hline TOTAL EU Expenditure & 142.50 & 425.89 & 0.23 & 0.86 & 1.17 & 2.35 & 23.48 \\
\hline
\end{tabular}

*Source: Own calculations based on Eurostat data; Ls = simulated EU lump-sum tax rate. 
As shown in Table no. 4 we simulate the ability of the future EU-lump-sum tax to replace the current EU own resources by applying the tax only to the EU citizens aged between 15-64 years old. The dependent categories of population aged between $0-14$ years and $65+$ years were excluded from the simulation. The second column of Table no. 4 shows the required the EU lump-sum tax rate to fully replace the current system of EU own resources. According to Eurostat, the population deemed to be active economically amounts to $66 \%$ of the total EU population in 2014. Therefore, as shown in Table no. 4, every EU citizen that is aged between 15-64 years should pay a yearly lump-sum tax of EUR 52.80 in order to fully replace the VAT-based EU resources in 2014. In order to fully replace the GNI-based resources, every citizen of the EU that is economically active should pay a lump-sum tax rate of EUR 296.12 person/year. In a scenario where lump-sum tax or a per capita charge would be imposed to fully replace the current system of the EU budget revenues, every EU citizen aged between 15-64 years should pay EUR 430.31 person/year. With respect to our five tax rates proposed for a lump-sum tax at the EU level, the revenue potential of this tax is presented in Table no. 6. The first three tax rates of EUR 1 person/year, EUR 3.65 person/year and EUR 5 person/year paid by the economically active EU citizens would produce EUR 0.33 bn., EUR 1.22 bn. and EUR 1.67 bn. The last two tax rates of EUR 10 person/year and EUR 100 person/year would produce EUR 3.35 bn. and respectively EUR 33.46 bn.

Also in Table no. 4 we compared the revenue potential of each lump-sum tax rate with the EU budget resources in 2014. The first two tax rates would cover less than $1 \%$ of total EU budget revenues. The next two tax rates would cover only a modest 1-2 \% of the total EU budget revenues. The last lump-sum tax rate proposed by us, of EUR 100 person/year would only cover $23.24 \%$ of the total EU revenues.

The above stated table shows that narrowing the tax base of lump-sum taxation, partly for equity consideration by targeting only the economically active citizens of EU, the revenue potential of the EU per capita charge is significantly lower. Even if lump-sum taxation is considered as one of the most efficient, simple and easy to collect, in order to fully replace all the EU budget current sources, a tax rate of EUR 430.21 person/year would be highly inequitable because is evading the ability to pay of taxpayers.

Table 5

Shifts in total National Contribution of Each EU Member to the EU Budget in Case of Lump-Sum Tax Enactment to Fully Replace the Current System of the EU Budget Resources

\begin{tabular}{|c|c|c|c|c|}
\hline & $\begin{array}{l}2014 \text { Population } \\
\text { with age between } \\
15-64 \text { years }\end{array}$ & $\begin{array}{c}\text { Percentage of each EU } \\
\text { member state to total EU } \\
\text { population aged between } 15 \text { - } \\
64 \text { years }\end{array}$ & $\begin{array}{c}\text { Contribution of each EU } \\
\text { member state to EU budget } \\
\text { using current system of EU } \\
\text { sources (GNI, VAT and TOR) } \\
\text { in } 2014\end{array}$ & $\begin{array}{l}\text { Lump-sum tax contribution } \\
\text { to EU budget (full } \\
\text { replacement of current EU } \\
\text { own sources) }\end{array}$ \\
\hline & Mil. & $\%$ & EUR Bn. & EUR Bn. \\
\hline EU (28 countries) & 334.58 & - & 132.96 & 132.96 \\
\hline Belgium & 7.39 & 2.21 & 5.23 & 2.94 \\
\hline Bulgaria & 4.78 & 1.43 & 0.46 & 1.90 \\
\hline Czech Republic & 6.94 & 2.07 & 1.51 & 2.76 \\
\hline Denmark & 3.71 & 1.11 & 2.51 & 1.48 \\
\hline Germany & 53.31 & 15.93 & 29.14 & 21.18 \\
\hline Estonia & 0.87 & 0.26 & 0.20 & 0.35 \\
\hline Ireland & 3.04 & 0.91 & 1.65 & 1.21 \\
\hline Greece & 7.21 & 2.16 & 1.95 & 2.87 \\
\hline Spain & 30.70 & 9.18 & 11.11 & 12.20 \\
\hline France & 43.49 & 13.00 & 20.97 & 17.28 \\
\hline Croatia & 2.80 & 0.84 & 0.43 & 1.11 \\
\hline Italy & 40.12 & 11.99 & 15.89 & 15.94 \\
\hline Cyprus & 0.57 & 0.17 & 0.16 & 0.23 \\
\hline Latvia & 1.32 & 0.39 & 0.27 & 0.52 \\
\hline Lithuania & 1.94 & 0.58 & 0.38 & 0.77 \\
\hline Luxembourg & 0.36 & 0.11 & 0.25 & 0.14 \\
\hline Hungary & 6.52 & 1.95 & 1.00 & 2.59 \\
\hline Malta & 0.28 & 0.08 & 0.08 & 0.11 \\
\hline Netherlands & 11.11 & 3.32 & 8.37 & 4.41 \\
\hline Austria & 5.61 & 1.68 & 2.87 & 2.23 \\
\hline Poland & 25.09 & 7.50 & 3.95 & 9.97 \\
\hline Portugal & 6.88 & 2.06 & 1.75 & 2.73 \\
\hline Romania & 13.17 & 3.93 & 1.46 & 5.23 \\
\hline Slovenia & 1.36 & 0.41 & 0.39 & 0.54 \\
\hline Slovakia & 3.57 & 1.07 & 0.72 & 1.42 \\
\hline Finland & 3.60 & 1.08 & 1.90 & 1.43 \\
\hline Sweden & 6.37 & 1.90 & 4.29 & 2.53 \\
\hline United Kingdom & 42.47 & 12.69 & 14.07 & 16.88 \\
\hline
\end{tabular}

*Source: Own calculations based on Eurostat data. 
The table no. 5 shows how the financial burden would shift between the EU member states, in the hypothetical case of lump-sum tax enactment to finance the EU budget. Therefore, we choose to compare total national contribution of each member state to the EU budget in 2014, using current system of sources (VAT-based sources, GNI-based sources and TOR- Traditional Own Resources) with the case of lump-sum tax. Table no. 5 presents considerable shifts of financial burden, when the contribution of the each EU member state to the EU budget is based on lump-sum tax and using population as tax base. In this scenario, it is important to underline that the five out of six founding states of the EU, namely Belgium, Germany, France, Luxembourg and Netherlands would decrease their contribution to the EU budget. Belgium, Luxembourg and Netherlands would pay approximatively $50 \%$ less than under current system of the EU budget resources. Italy would be the only country which would not incur significant modifications in her contribution to the EU budget in a scenario of lump-sum tax enactment.

Using population as the exclusive criteria to calculate each EU member state contribution to the EU budget, we observe notable shifts of financial burden especially to new members of the EU. The EU member states such as Bulgaria, Czech Republic, Estonia, Greece, Croatia, Latvia, Lithuania, Hungary, Poland, Portugal, Romania, Slovenia and Slovakia would need to incur substantial increases of their contribution to the EU budget.

Based on the results of simulations presented in Table no. 5, we can conclude that lump-sum tax is not only inequitable by treating all individuals equally, but is also inequitable when is treating equally a group of heterogeneous countries, such as the EU member states. Charging a per capita tax at the EU level in order to finance the EU budget would impose an unbearable financial stress on the net recipients under the current EU Budget, in comparison with the current net contributors. Even if lumpsum taxation is deemed to be the most efficient tax, this levy is ignoring the equity principle or the ability to pay at both levels - at taxpayer and also at the state level.

\section{Conclusions}

The scientific problem this paper is focusing on represents the possible reform of revenue side of the EU budget and the possibility of enacting the future EU lumpsum tax as an appropriate replacement of current system of the EU budget own resources. Therefore, the aim of the paper is to evaluate, whether lump-sum tax could be considered as the potential EU tax, referring to its in-built features to close in the sustainability gaps of current tax systems across the EU as defined by Schratzenstaller et al. (2016).

It is important to mention that this type of taxation has not been discussed as a potential candidate on the EU own resource yet. Moreover, there are no studies which research the potential of lump-sum tax to replace the current system of the EU own resources. The lump-sum tax is used as the ideal, first-best tool, to compare the efficiency and equity level of second-best tax instruments. With respect to the viability of lump-sum taxes there is an ongoing conflict between fundamental principles (i.e. evaluation criteria) that underlie the lump-sum tax - efficiency and equity. By definition, the lump-sum is one of the most efficient tax tools that the government can make use. It is a tax that does not create deadweight loss and has a low administration costs.

However, even if the tax is respecting the efficiency criteria it is overlooking the equity criteria. The lump-sum tax does not consider the ability-to-pay principle, thus becoming solely a theoretical tool. The past experiences with lump-sum taxes have shown that this tax is highly unpopular, regressive, unfair towards low-income taxpayers and politically difficult to implement. In order to qualify as a potential candidate to finance EU budget, the lump-sum tax needs to be assessed in the particular framework of the EU. One peculiar evaluation of lumpsum tax is related with its ability to enhance Europe2020 strategy of "smart, sustainable and inclusive growth". A future EU lump-sum tax could contribute to Europe2020 strategy by decreasing the weight of the EU tax systems on labor taxation, thus enhancing employment, increasing tax compliance and reducing tax evasion. However, the future EU lump-sum tax has no ability to reduce climate change, poverty and social exclusion or to increase energy efficiency and research and development at the EU level.

A sustainable tax system is defined by Nerudova et al. (2016) as the tax system which contributes to economic, social, environmental and institutional sustainability. It is a tax system that allows meeting the needs of present generation without limiting the future generations to meet their own needs. Therefore we evaluate the ability of a hypothetical the future EU lump-sum tax to close-in the tax system sustainability gaps which affect the four pillars of sustainability - economic, social, environmental and institutional pillar.

Consequently, lump-sum taxation should be evaluated taking into consideration the current challenges of tax systems across the EU and the capacity of the lump-sum taxation to close the tax sustainability gaps. Hence the lump-sum tax weakness comes from its low redistribution power and the incapacity to reduce inequality. Also, lumpsum tax would have no effect on reducing tax competition or correcting the behavior related to harmful good consumption (i.e. corrective taxation). The only advantages of lump-sum tax lies in its ability to decrease labor taxation and lower tax evasion. In conclusion, the EU lump-sum tax might help to contribute to closing of the sustainability gap in the form of tax compliance and tax fraud. On the other hand, lump-sum taxation could have a mild effect on decreasing the dependence of tax systems on labor taxation.

The paper researches the potential of the lump-sum tax levied at the EU level, by estimating the tax revenues which could be raised if the tax would be imposed on every EU citizen. Alternatively, the lump-sum tax potential is assessed by excluding the economically inactive population aged between $0-14$ years and $65+$ years.

One major factor that would make lump-sum tax applicable at the EU level stems out of a low and affordable tax rate, which would not significantly affect low and middle income individuals. On the other hand, the 
lump-sum tax base is a broad one, taking into consideration that the population of the EU is more than 500 Mil.

Tax revenues are estimated by imposing lump-sum tax at different rates, starting with lower rate of EUR 1 per person paid annually and the upper rate of EUR 100 paid annually by every EU citizen. The results of the simulations show that the first three proposed tax rates would bring a low level of revenues when compared with actual the EU Own resources. In comparison with low tax rates, the upper limit of EUR 100 per person would be highly unpopular and regressive, affecting the poor categories of the EU citizens. Moreover, the simulation also revealed, that in order to completely replace the actual contributions of the EU member states, the annual lumpsum tax would have to amount up to EUR 283 per person.

We conclude that the future EU lump-sum tax cannot fully replace the current system of the EU budget own resources, due to equity considerations. Therefore, the lump-sum tax is not an appropriate candidate to be included for the reform of revenue side of the EU budget.

\section{References}

Benedetto, G. (2013). The EU budget after Lisbon: rigidity and reduced spending?. Journal of Public Policy, 33 (3), 345. https://doi.org/10.1017/S0143814X13000172

Begg, I., \& Heinemann, F. (2006). New budget, old dilemmas. Centre for European Reform Briefing Note.

Besley, T., Preston, I., \& Ridge, M. (1997). Fiscal anarchy in the UK: modelling poll tax noncompliance. Journal of Public Economics, 64(2), 137-152. https://doi.org/10.1016/S0047-2727(96)01625-8

Cottarelli, C. (2016). A European fiscal union: the case for a larger central budget. Economia Politica, 33(1), 1-8. https://doi.org/10.1007/s40888-016-0026-2

Elkins, D. (2006). Horizontal equity as a principle of tax theory. Yale Law \& Policy Review, 24(1), 43-90.

European Commission. (2004). Financing the European Union. Commission Report on the Operation of the Own Resources System. COM (2004)505. Brussels: European Commission.

European Commission. (2010). Europe 2020: A Strategy for Smart, Sustainable and Inclusive Growth: Communication from the Commission. Publications Office of the European Union.

Fenge, R., \& Wrede, M. (2007). EU financing and regional policy: vertical fiscal externalities when capital is mobile. FinanzArchiv: Public Finance Analysis, 63(4), 457-476. https://doi.org/10.1628/001522107X268970

Fuest, C., Heinemann, F., \& Ungerer, M. (2015). Reforming the financing of the European Union: A proposal. Intereconomics, 50(5), 288-293. https://doi.org/10.1007/s10272-015-0553-Z

Gans, J., King, S., Stonecash, R., \& Mankiw, N. G. (2011). Principles of economics. Cengage Learning.

Graaff, J. de V. (1987) Lump sum taxes; in The New Palgrave: A Dictionary of Economics, Vol. 3, J. Eatwell et al., eds. London: Macmillan. https://doi.org/10.1057/978-1-349-95121-5_1048-1

Heinemann, F., Mohl, P., \& Osterloh, S. (2008a). Reform options for the EU own resources system (Vol. 40). Springer Science \& Business Media. https://doi.org/10.1007/978-3-7908-2066-9

Heinemann, F., Mohl, P., \& Osterloh, S. (2008b). Criteria for a Fair and Efficient Own Resources System in Reform Options for the EU Own Resources System, 3-9. ZEW Economic Studies.

Heinemann, F., Mohl, P., \& Osterloh, S. (2009). Who's afraid of an EU tax and why? -revenue system preferences in the European Parliament. The Review of International Organizations, 4(1), 73-99. https://doi.org/10.1007/s11558-0089046-1

Heinemann, F., Mohl, P., \& Osterloh, S. (2010). Reforming the EU Budget: Reconciling Needs with Political-Economic Constraints. European Integration, 32(1), 59-76. https://doi.org/10.1080/07036330903375149

Hillman, A. L. (2003). Public finance and public policy: responsibilities and limitations of government. Cambridge University Press.

Iara, A. (2015). Wealth distribution and taxation in EU Members. Office for Official Publications of the European Communities. Available from internet at: https://ec.europa.eu/taxation_customs/sites/taxation/files/docs/body/ taxation_paper_60.pdf

Le Cacheux, J. (2005). European Budget: The poisonous budget rebate debate. Notre Europe. Available from internet at: http://www.notre-europe.eu/media/etud41-en.pdf?pdf=ok

Le Cacheux, J. (2007). Funding the EU budget with a genuine own resource: the case for a European tax. Notre Europe Studies No. 57, Paris.

Myles, G. D., \& Hindriks, J. (2004). Intermediate Public Economics. 
Neheider, S., \& Santos, I. (2011). Reframing the EU Budget Decision-Making Process. Journal of Common Market Studies, 49(3), 631-651. https://doi.org/10.1111/j.1468-5965.2010.02148.x

Nerudova, D., Rozmahel, P., Dobranschi, M., Litzman, M., Hampel, D., Janova, J. and Brogger, B. (2016). Sustainability of the Taxation System. Mimeo.

Nu-ez Ferrer, J. (2007). The EU Budget: The UK Rebate and the CAP Phasing them both out. CEPS Task Force Report, CEPS, Brussels.

Nú-ez-Ferrer, J.., \& Katarivas, M. (2014). What are the effects of the EU budget: Driving force or drop in the ocean? CEPS Special Reports, 86.

Ramsey, F. P. (1927). A Contribution to the Theory of Taxation. The Economic Journal, 37(145), 47-61. https://doi.org/10.2307/2222721

Richter, S. (2006). On the Future of the Financial Redistribution across Member States in the EU. Acta Oeconomica, 56(1), 1-43. https://doi.org/10.1556/AOecon.56.2006.1.1

Rothbard, M. N. (1995). Making economic sense. Ludwig von Mises Institute.

Sansonetti, P., Hostettler, D., \& Funfschilling, A. (2011). Lump-sum or forfeit taxation: a reform driven by pragmatism. Attorteys at Law. Schellenberg Wittmer. Zurich. Available from internet at: http://www.swlegal.ch/CMSPages/GetFile. aspx?disposition=attachment\&nodeguid=a245e714-cb2a-404c-a48d-cc 1 b $6 b 432829$

Sapir, A. (2003). An Agenda for a Growing Europe: Making the EU Economic System Deliver: Report of an Independent High-level Study Group Established on the Initiative of the President of the European Communities. European Commission.

Schratzenstaller, M. (2013): The EU Own Resources System - Reform Needs and Options. Intereconomics, 48(5), 303313. https://doi.org/10.1007/s10272-013-0473-8

Schratzenstaller, M., Krenek, A., Nerudova, D., \& Dobranschi, M. 2016. EU Taxes as Genuine Own Resource to Finance the EU Budget - Pros, Cons and Sustainability-oriented Criteria to Evaluate Potential Tax Candidates. FairTax Working Paper No. 03, 81p.

Smith, A. (1776). Wealth of nations. Published in 2005 by University of Chicago Bookstore.

Stiglitz, J. E., Sen, A., \& Fitoussi, J. P. (2010). Report by the commission on the measurement of economic performance and social progress. Paris: Commission on the Measurement of Economic Performance and Social Progress.

Tabellini, G. (2003). Principles of policymaking in the European Union: an economic perspective. CESifo Economic Studies, 49(1), 75-102. https://doi.org/10.1093/cesifo/49.1.75

Tam, H. (2004). The Humean critique of lump sum taxation (or the implausibility of pure lump sum taxes in autocracy). Public Choice, 118(1/2), 61-76. https://doi.org/10.1023/B:PUCH.0000013800.88314.34

The article has been reviewed.

Received in October, 2016; accepted in October, 2017. 